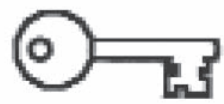

F.P. Graham Publishing Co.

\title{
Modulation of $\alpha$-Synuclein Expression in Transgenic Animals for Modelling Synucleinopathies - is the Juice Worth the Squeeze?
}

\author{
VLADIMIR L. BUCHMAN* and NATALIA NINKINA \\ School of Biosciences, Cardiff University, Museum Avenue, Cardiff, CF10 3US, UK. buchmanvl@cf.ac.uk
}

(Submitted 24 May 2008; Revised 17 July 2008; In final form 17 July 2008)

\begin{abstract}
Studies of various animal models have made a substantial contribution to the recent progress in understanding the molecular and cellular basis of neurodegenerative disorders. Modelling of neurodegeneration by genetic alteration of laboratory animals became one of the most powerful tools of modern experimental neurology. The crucial event in pathogenesis of neurodegenerative diseases known as synucleinopathies is modification of $\alpha$-synuclein metabolism caused by missense mutations, increased expression of the gene, or impaired degradation or intracellular compartmentalisation of the protein. Therefore, manipulations with expression of $\alpha$-synuclein in laboratory animals were widely used for creating models of these diseases. In the present review we discuss strong and weak sides of such models, what has been already learned from studies of these animals and what types of models might be useful to further our knowledge about pathogenesis of different synucleinopathies.
\end{abstract}

Keywords: Synuclein; Synucleinopathy; Inclusions; Transgenic animals; Animal models of diseases; Aggregation; Cell death; Multiple system atrophy; Motoneurons; Motor dysfunction; Parkinson's disease; Dopaminergic neurons

\section{INTRODUCTION}

In the last decade substantial progress has been achieved in understanding molecular and cellular events associated with neurodegeneration. The pivotal role of particular proteins in the development of specific pathologies has been revealed, for example, amyloid $\beta$-protein precursor (APP) and tau for Alzheimer's disease, superoxide dismutase (SOD) for ALS and huntingtin for Huntington's disease. The crucial moment for studies of aetiology and pathogenesis of Parkinson's disease (PD) was the revealing of $\alpha$-synuclein as a causative factor for both familial and idiopathic forms of this disease (Polymeropoulos et al., 1997; Spillantini et al., 1997). Further studies demonstrated that mishandling of this protein by various types of neurons or glial cells is associated with several neurological disorders, including dementia with Lewy bodies (DLB), multiple system atrophy (MSA) and certain others. These diseases were coalesced into a new group named synucleinopathies (Goedert and Spillantini, 1998; Spillantini and Goedert, 2000; Galvin et al., 2001; Marti et al., 2003). The major histopathological feature of synucleinopathies is accumulation of fibrillated $\alpha$-synuclein that forms characteristic inclusions in the perikaria, neurites and, sometimes, nuclei of affected cells.

*Corresponding author: Tel.: +442920879068; E-mail: buchmanv1@cf.ac.uk

ISSN 10298428 print/ ISSN 1476-3524 online. (C) 2008 FP Graham Publishing Co., www.NeurotoxicityResearch.com 
Accumulation and aggregation of $\alpha$-synuclein can be caused by many factors, including increased expression due to duplication or triplication of the gene, reduced degradation of the protein or its disturbed transport to synaptic terminals, where $\alpha$-synuclein normally resides and functions. Rare missense mutations (A53T, A30P and E46K have been identified so far) affect intrinsic properties of $\alpha$-synuclein; this could lead to pathology associated with familial forms of PD. However, for idiopathic forms of PD and other synucleinopathies that comprise the majority of cases, some external factors should trigger changes of the metabolism of normal $\alpha$-synuclein protein.

Although inclusions are the most prominent feature of synucleinopathies, their role in dysfunction and death of neurons is not clear. A growing body of evidence suggests that intermediates of $\alpha$-synuclein aggregation, oligomers and protofibrils, but not final products of this process, fibrils, are toxic for neurons (reviewed in Caughey and Lansbury, 2003; Dev et al., 2003; Fink, 2006; Uversky, 2007). Another key and still unanswered question is why particular cell populations are more sensitive than others to $\alpha$-synuclein pathology. Most importantly, poor understanding of the mechanisms of $\alpha$-synucleininduced neurodegeneration precludes development of therapies that might target dysfunction of this protein.

Neurodegeneration is an extremely complicated process and clear understanding molecular and cellular events leading to pathology requires combination of clinical and experimental studies. Although in vitro and tissue culture studies were quite useful for revealing certain intracellular mechanisms of neurodegeneration, only modelling of particular types of neurodegenerative processes in laboratory animals could provide a tool for experimental studies in the context of the whole organism. Various animal models were used for studying synucleinopathies but the most obvious way of creating such models - by genetic manipulation of $\alpha$-synuclein expression - appeared to be not the most straightforward and fruitful. In this review we describe what has been achieved in these studies and what questions are waiting for better models that should help in finding comprehensive answers.

\section{Pan-Neuronal Expression of $\alpha$-Synuclein in Transgenic Mice}

The first attempt to model synucleinopathy in transgenic mice was made by Masliah and colleagues at the turn of the century (Masliah et al., 2000). A relatively strong, although non-specific PDGF $\beta$ gene promoter was used to control expression of the wild type human $\alpha$-synuclein. This allowed achieving relatively high levels of human protein expression in the nervous system of five independent mouse lines. Progressive accumulation of cytoplasmic and nuclear inclusions in neurons of deep cortical layers, CA3 area of the hippocampus, ophthalmic bulb and, rarely, substantia nigra, was observed in all these mice from the age of two months. These inclusions were positive for ubiquitin and human $\alpha$-synuclein but not endogenous mouse $\alpha$-synuclein. In contrast to Lewy bodies and other inclusions characteristic for human synucleinopaties, inclusions in transgenic mouse neurons consisted of amorphous aggregates and not $\alpha$-synuclein fibrils (Masliah et al., 2000; 2001). Only animals of line D with the level of human $\alpha$-synuclein expression approximately five times higher than in other lines developed pathology - at the age of 12 months these animals displayed a marked decrease of the level and activity of tyrosine hydroxylase in the striatum, and motor dysfunction that could be revealed in a rotarod test. However, no loss of dopaminergic neurons was found in the substantia nigra of these mice (Masliah et al., 2000). Further studies of line D in several laboratories revealed other but usually subtle changes of the phenotype (Hashimoto et al., 2001; 2004; Masliah et al., 2001; 2005; Klucken et al., 2004; Winner et al., 2004; 2008; Bar-On et al., 2006), including negative effect of human asynuclein expression on survival but not proliferation of neuronal precursor cells (Winner et al., 2004; 2008). Interestingly, coexpression of $\alpha$-synuclein and $\beta$-amyloid peptides had substantial effect on pathological changes in the nervous system of double transgenic mice. Fibrillated human $\alpha$-synuclein was found in neuronal inclusions along with amorphous protein, and progressive degeneration of synapses and neurons of cholinergic system developed in the brain of ageing animals (Masliah et al., 2001). Therefore, neuronal pathology in double transgenic mice resembled pathology characteristic to dementia with 
Lewy bodies and Lewy body variant of Alzheimer's disease. In another laboratory PDGF $\beta$ promoter was used to regulate expression of either wild type or A53T mutant human $\alpha$-synuclein (Sharon et al., $2001 ; 2003)$. Both studies focused on interaction of $\alpha$-synuclein with polyunsaturated fatty acids, and although progressive accumulation of soluble oligomers in the brain of transgenic mice was observed (Sharon et al., 2003), changes of the phenotype have not been reported for any of several independent lines of these transgenic animals.

High levels of $\alpha$-synuclein expression in the majority of neurons throughout the nervous system of transgenic mice was also achieved in a number of laboratories by using a prion protein ( $\mathrm{PrP})$ gene promoter of either hamster (Gomez-Isla et al., 2003; Fortin et al., 2004) or mouse origin (Giasson et al., 2002; Lee et al., 2002; Gispert et al., 2003). Several animal lines expressing various levels of wild type or mutant (A53T or A30P) $\alpha$-synuclein were generated in each laboratory. Pathological phenotypes were often observed in mice expressing mutant variants of the protein while animals expressing in their neurons even high levels of wild type protein were completely spared of pathology (Giasson et al., 2002; Lee et al., 2002; Gispert et al., 2003; Gomez-Isla et al., 2003). However, even with mutant proteins results were not very consistent. Homozygous transgenic mice from two independent lines expressing A53T human $\alpha$-synuclein developed motor dysfunction with paralysis that led to eventual death at the age of approximately 16 months. However, hemizygous animals from one of these lines never developed any sign of pathology, while the onset of pathology for hemizygous mice from another line was around 22-28 months (Giasson et al., 2002).

Similar results were reported by Lee et al. (2002) who also observed pathological phenotype in transgenic mice expressing A53T human $\alpha$-synuclein. In studied mouse lines an inverse correlation was found between the level of this transgene expression and the onset of the development of lethal neuronal pathology. Histological changes that included $\alpha$-synuclein-positive and ubiquitin-positive inclusions in neuronal cell bodies and processes, damaged neuronal mitochondria, and apoptotic death of neurons were observed in many areas of the nervous system (Lee et al., 2002; Martin et al., 2006). However, as in the previously described study (Giasson et al., 2002), these changes were most common for motoneurons of the spinal cord. The clinical manifestation of the pathology was mainly caused by dysfunction and death of these neurons. The dopaminergic nigrostriatal system of these mice was generally unaffected, although changes of dopamine neurotransmission were reported in the later study (Unger et al., 2006). No pathology was found in mice with low level of A53T or high level of either wild type or A30P human $\alpha$-synuclein expression (Lee et al., 2002).

Different results were obtained in another laboratory that used PrP promoter-driven expression of human $\alpha$-synuclein transgenes (Gomez-Isla et al., 2003). Five lines expressing different forms of this protein were produced but in four of them expression of wild type or A53T or A30P protein did not trigger pathology in transgenic mice even at the age of 20 months although expression levels of human proteins were substantially higher than the level of endogenous mouse $\alpha$-synuclein. Only mice from the line Tg5093 with the highest level of A30P $\alpha$-synuclein expression displayed pathological phenotype - homozygous animals developed progressive motor dysfunction from the age of 4-7 months, whereas much later onset (8-16 months) was typical for hemizygous animals. However, no pathological inclusions, deposits or other evidence of human $\alpha$-synuclein aggregation were found even in homozygous Tg5093 mice that accumulated large amounts of this protein in their neurons and developed obvious clinical signs of pathology. A widespread gliosis was the only histopathological manifestation of degenerative changes in the nervous system of these mice. Although minimal if any changes were observed in the nigrostriatal system, dopaminergic neurons of substantia nigra of Tg5093 animals were more sensitive to the toxic effect of 1-methyl-4-phenyl-1,2,3,6-tetrahydropyridine (MPTP) but not rotenone (Gomez-Isla et al., 2003; Nieto et al., 2006). Similar observations were made by another group - expression of A53T human $\alpha$-synuclein induced progressive motor dysfunction without any signs of human $\alpha$-synuclein aggregation in the nervous system of transgenic mice (Gispert et al., 2003). This phenotype was not noticed in mice of a line that expressed lower levels of the same transgene, however ablation of the 
expression of endogenous mouse $\alpha$-synuclein by cross breeding of these mice with $\alpha$-synuclein null mutant mice, resulted in spinal motoneuron dysfunction and paralyses at around 16 months of age (Cabin et al., 2005). This result might suggest that at least for some neuronal populations expression of $\alpha$-synuclein during development makes them protected from certain neurotoxic insults in postnatal period.

A promoter of the mouse Thy-1 gene was also widely used for generation of mice with pan-neuronal expression of $\alpha$-synuclein. In contrast to unsuccessful attempts with PrP promoter-driven expression, Thy-1 promoter was associated with reproduction of certain pathological changes in mice expressing not only mutant but also wild type human $\alpha$-synuclein (van der Putten et al., 2000; Rockenstein et al., 2002; Fleming et al., 2004; Chandra et al., 2005). From the age of 3 months mice expressing either wild type or A53T human $\alpha$-synuclein developed progressive motor dysfunction accompanied by pathological changes in synapses, axons and cell bodies of neurons, predominantly motoneurons of the spinal cord and the brainstem (van der Putten et al., 2000). Relatively early changes in the sensory and motor systems were also revealed by various behavioural tests in another transgenic mouse line but no pathological inclusions were found in neuronal cell bodies or processes of these mice (Rockenstein et al., 2002; Fleming et al., 2004). No substantial dysfunction of dopaminergic neurons of the substantia nigra was observed, which is not surprising because it is well known that expression levels of Thy-1 promoterdriven transgenes in these neurons is usually quite low. Nevertheless, further studies of these mice revealed increased sensitivity to subtoxic doses of MPTP (Song et al., 2004), paradoxical effect of 3,4-L-dihydroxyphenylalanine (L-DOPA), abnormal responses to apomorphine and amphetamine (Fleming et al., 2006), and stimulation of $\alpha$-synuclein aggregation by paraquat (Fernagut et al., 2007), which all might reflect sub-pathological changes in their nigrostriatal system.

In contrast to transgenic mice described above, in heterozygous animals from several lines produced in another laboratory, accumulation of either wild type or A30P human $\alpha$-synuclein in neuronal cell bodies and neurites was accompanied by its aggre- gation, as revealed by biochemical analysis (Kahle et al., 2000; 2001). However, only in one of these lines aggregation and hyperphosphorylation of $\alpha$-synuclein lead to the development of intracellular inclusions, dysfunction of motor and cognitive functions, and astrocytosis predominantly in the spinal cord and the brainstem. The onset of these changes was substantially earlier for homo- than for hemizygous animals (Neumann et al., 2002; Freichel et al., 2007). Changes of the activity of certain mitochondrial enzymes (Poon et al., 2005) and increased tau phosphorylation (Frasier et al., 2005) were also found in the nervous system of these mice but sensitivity of their dopaminergic neurons to MPTP toxicity was not altered (RathkeHartlieb et al., 2001).

Several mouse lines with roughly similar levels of expression (5-10 times higher than the level of endogenous $\alpha$-synuclein expression) of wild type, A30P or A53T human $\alpha$-synuclein or wild type mouse $\alpha$-synuclein under control of Thy-1 promoter were used to compare the ability of these proteins to trigger pathological changes (Chandra et al., 2005). Age-related progressive neurodegeneration with $\alpha$-synuclein aggregation, astrocytosis, spinal motoneuron loss and paralyses of limbs were observed in mice expressing either form of human protein. However, the penetrance of phenotype development at 16 months of age was over $70 \%$ in lines expressing mutant forms and only $16 \%$ in lines expressing wild type human $\alpha$-synuclein (Chandra et al., 2005; Gallardo et al., 2008). Pathology did not develop in mice expressing even high levels of wild type mouse $\alpha$-synuclein (Chandra et al., 2005).

Recently, consequences of Thy-1 promoter-driven expression of a new type of modified human $\alpha$-synuclein have been checked in transgenic mice. A mutation that results in the substitution of tyrosine to cysteine at position 39 of $\alpha$-synuclein molecule has not been found in association with any of hereditary synucleinopathies but in vitro studies have demonstrated that the ability of Y39C $\alpha$-synuclein to form dimers via disulfide bonds substantially increases its propensity to aggregate and the ability to cause cytotoxicity. Consequently, even a relatively low level of transgene expression (approximately $150 \%$ of the level of endogenous $\alpha$-synuclein expression) triggered accumulation of 
$\alpha$-synuclein oligomers, formation of intraneuronal inclusions and apoptotic death of neurons (Zhou et al., 2008). These molecular and cellular changes were followed by progressive decline of motor and cognitive functions in ageing mice. However, as for the majority of mouse lines discussed above, substantia nigra neurons were not affected in these mice and pathological changes were restricted to the cerebral cortex and spinal cord.

Studies of transgenic mouse lines with pan-neuronal expression of human $\alpha$-synuclein isoforms made substantial contribution to our understanding molecular mechanisms of the development of synucleinopathies. For instance, it has been clearly demonstrated that expression of wild type human $\alpha$-synuclein could trigger neuronal pathology but only when the level of transgene expression in neurons is substantially higher than the level of endogenous mouse $\alpha$-synuclein expression in these cells. Even lines with high levels of human wild type protein expression show late onset and low penetrance of pathology suggesting that for the development of pathological changes in the nervous system of these mice accumulation of wild type human $\alpha$-synuclein should be complemented by some additional unidentified internal and/or environmental factors. These results are in agreement with analysis of familiar forms of synucleinopathies caused by duplications or triplications of $\alpha$-synuclein gene that also revealed incomplete penetrance of the disease for carriers of these mutations (Singleton et al., 2003; Farrer et al., 2004). The absence of pathology in mice expressing high levels of mouse $\alpha$-synuclein is consistent with in vitro data that demonstrated lower propensity to aggregate for mouse protein compared to human protein (reviewed in Uversky and Fink, 2002; Fink, 2006; Uversky, 2007). This also suggests that the development of pathology could not be triggered simply by enhancing a normal function of $\alpha$-synuclein. Another clear conclusion that could be drawn from the analysis of the above described mouse lines is that the expression level threshold required for triggering pathology is substantially lower for proteins carrying Parkinson's diseaseassociated amino acid substitutions than for wild type human protein. This could be considered as a direct experimental confirmation of a causative role for corresponding gene mutations in aetiology of familial forms of Parkinson's disease.
Aggregation of human $\alpha$-synuclein is common for transgenic animals that developed clinical signs of neurological pathology although in several lines such pathology was not accompanied by aggregation of this protein and, conversely, mice from other lines with multiple $\alpha$-synuclein-positive inclusions in their nervous system did not develop any pathology. Therefore, studies of these mouse models failed to clarify the role of $\alpha$-synuclein aggregation in the development of clinical signs of pathology. Even those of transgenic mouse lines that displayed obvious progressive neurological phenotype with histopathological changes similar to changes typical for synucleinopathies had one serious disadvantage as models for these diseases - localisation of pathology. In the majority of cases, the spinal cord was the most affected region of the nervous system of these mice, and the observed phenotypical changes mainly reflected damage or loss of motoneurons and their axons, while spinal pathology is not a common feature of human synucleinopathies. Further studies are required to reveal if this was the result of high levels of expression of all utilized transgenes in spinal motoneurons or an increased sensitivity of these cells to toxic effects of human $\alpha$-synuclein.

\section{Cell Type Specific Expression of $\alpha$-Synuclein in Transgenic Mice}

A number of attempts were made to create transgenic mouse models of a particular synucleinopathy. For creation of an animal model of PD several laboratories expressed various forms of $\alpha$-synuclein specifically in dopaminergic neurons. Similarly, specific expression of this protein in oligodendrocytes was applied for modelling of MSA.

\section{Expression in Dopaminergic Neurons}

A common approach for producing mice with dysfunction of the dopaminergic system was specific expression of human $\alpha$-synuclein in dopaminergic neurons using tyrosine hydroxylase $(\mathrm{TH})$ promoter. Studies of the first sets of such transgenic mouse lines generated independently in two laboratories produced rather disappointing results. Animals expressing either wild type or mutant (A53T or A30P) human $\alpha$-synuclein did not develop motor or other behavioural dysfunction, and no histopathological changes were observed in their nervous 
systems despite accumulation of the human protein in cell bodies and processes of dopaminergic neurons (Matsuoka et al., 2001; Rathke-Hartlieb et al., 2001). Also, no changes were found in striatal dopamine metabolism, number of dopaminergic neurons in the substantia nigra, or their sensitivity to the toxic effect of MPTP (Matsuoka et al., 2001; Rathke-Hartlieb et al., 2001; Manning-Bog et al., 2003). Although paraquat treatment induced aggregation of the wild type or mutant form of human $\alpha$-synuclein in dopaminergic neurons, they were resistant to the toxic effect of this herbicide (Manning-Bog et al., 2003). No pathological changes were revealed in studies of several other more recently generated mouse lines with $\mathrm{TH}$ promoter-driven expression of human $\alpha$-synuclein (Wakamatsu et al., 2007; 2008).

Changes in the dopaminergic system were also minimal in a line of mice expressing wild type human $\alpha$-synuclein under control of TH promoter that was produced in another laboratory (Richfield et al., 2002). However, mice expressing under control of this promoter a double mutant human $\alpha$-synuclein (with both A53T and A30P amino acid substitutions) developed a motor deficit accompanied by progressive axonal and synaptic pathology, changes of dopamine metabolism, dysfunction of ubiquitin-proteasome system, and loss of neurons in their nigrostriatal system (Richfield et al., 2002; Thiruchelvam et al., 2004; Chen et al., 2006). Dopaminergic neurons of the substantia nigra were more sensitive to combined toxicity of herbicides paraquat and maneb but did not have pathological inclusions or aggregates of $\alpha$-synuclein (Thiruchelvam et al., 2004). Different results were obtained in another laboratory that produced transgenic mice expressing the same double mutant human $\alpha$-synuclein under control of three different promoters, including TH promoter. These mice did not develop any pathological phenotype, and only progressive structural and functional changes of mitochondria were found in their neurons. Neither pathological inclusions, nor loss of neurons or their synapses, nor astrogliosis was observed (Maskri et al., 2004; Stichel et al., 2007). It is not clear why results of these two laboratories are so contradictory.

Truncated $\alpha$-synuclein species lacking $\mathrm{C}$-terminal sequences have increased propensity to aggregate in vitro and are abundant in pathological inclusions found in brains of patients suffering from synucleinopathies. Nevertheless, aggregated $\alpha$-synuclein was not found in dopaminergic neurons of mice expressing a C-terminally truncated, $\alpha 1-130$, variant of human protein under control of TH promoter (Wakamatsu et al., 2008). As in the case of mice described above (Richfield et al., 2002), in the absence of aggregates these mice still developed selective loss of dopaminergic neurons in the substantia nigra, reduced striatal dopamine level and, consequently, motor dysfunction. However, these changes were not progressive and neuronal loss took place soon after activation of transgene expression at the early embryonic stage (Wakamatsu et al., 2008). In contrast, mice with $\mathrm{TH}$ promoterdriven expression of another C-terminally truncated, $\alpha 1-120$, variant of human $\alpha$-synuclein developed progressive decrease of locomotor activity, which correlated with decreasing level of striatal dopamine and formation of pathological inclusions in dopaminergic neurons in the substantia nigra (Tofaris et al., 2006). No loss of these neurons was revealed, although the recent study suggested that their sensitivity to stress could be increased (Tofaris et al., 2006; Michell et al., 2007).

In summary, expression of $\alpha$-synuclein in transgenic mice under control of TH promoter turned to be inefficient for creating mouse models of PD. Triggering of some pathological changes in dopaminergic neurons was achieved only when artificially engineered mutant forms of human protein were used but the whole spectrum of PD pathology has not been reproduced in any of these models. The most probable explanation of these failures is the low level of TH promoter-regulated expression of transgenes. Because of this low expression, accumulation of exogenous $\alpha$-synuclein in mouse dopaminergic neurons does not reach the level required for triggering pathological changes. It is well documented that rodent dopaminergic neurons are more resistant than human neurons to toxic drugs causing PD, like MPTP. It is feasible that a pathological threshold level of $\alpha$-synuclein is also substantially higher for mouse neurons than for human neurons and, therefore, successful modelling of pathology in mice requires stronger dopaminergic neuron-specific promoters for expression of $\alpha$-synuclein. 


\section{Expression in Oligodendrocites}

Attempts to create mouse models of MSA were much more successful. The approach for modelling MSA was based on ectopic expression of wild type human $\alpha$-synuclein in mouse oligodendrocytes because $\alpha$-synuclein-positive inclusions in these cells are the major histopathological hallmarks of this idiopathic disease. Aggregation and hyperphosphorylation of $\alpha$-synuclein, and formation in the perinuclear area of oligodenrocytes of inclusions that resembled inclusions in oligodendrocytes of MSA patients were achieved in several mouse lines with transgene expression regulated by oligodendrocyte-specific proteolipid protein (PLP) gene promoter (Kahle et al., 2002). However, these animals did not develop any motor dysfunction, and degeneration of neurons or axons was not noticed in their nervous system, probably due to low levels of transgene expression. Nevertheless, they appeared to be more sensitive to oxidative stress because a mitochondrial inhibitor, 3-nitropropionic acid (3-NP), triggered development of substantially more severe neurological pathology in these transgenic mice than in control wild type mice (Stefanova et al., 2005). Importantly, regional localisation of neurodegeneration and atrophy within the brain of transgenic mice closely resembled localisation of pathology typical for MSA. These changes along with widespread astrogliosis and microglia activation led to gradual decline of animal motor performance in various behavioural tests (Stefanova et al., 2005; 2007a,b,c).

Another, 2',3'-cyclic nucleotide-3'-phosphodiesterase (CNP), gene promoter also produced relatively low total brain level of human $\alpha$-synuclein expression in transgenic mice, but because this expression was restricted to oligodendrocytes, the level of ectopic protein in these cells was substantially higher than the level of endogenous mouse $\alpha$-synuclein (Yazawa et al., 2005). Aggregation of human $\alpha$-synuclein and progressive accumulation of its fibrils observed in oligodendrocytes led to their degeneration and death as well as autophagocytosis of axonal myelin sheets. Interestingly, endogenous $\alpha$-synuclein was also involved in the development of pathological changes in neurons of these mice - abnormal accumulation of mouse protein was found in axons and presynaptic terminals. The outcome of above changes was the loss of both glial and neuronal cells in many regions of the brain of transgenic mice and the impairment of their motor behaviour (Yazawa et al., 2005).

Pathological phenotype was even more pronounced in a line of transgenic mice expressing very high level of human $\alpha$-synuclein under control of the myelin basic protein gene promoter (Shults et al., 2005). In contrast to mice from other lines with lower levels of transgene expression that lived longer than 18 months, all mice from this line developed severe neurological alterations at 2-4 months of age, resulting in death at the age of 6 months. Histological pathology in the brain of affected animals included astrogliosis, and structural changes of axons and their myelin sheets followed by degeneration of these structures. It has been suggested that the above changes were triggered by dysfunction of oligodendrocytes, which in turn was caused by aggregation of human $\alpha$-synuclein in these cells and formation of inclusions similar to inclusions seen in oligodendrocites of MSA patients (Shults et al., 2005).

Why did overexpression of $\alpha$-synuclein in relevant cell populations produce respectable models of MSA but not PD pathology? It is feasible that neurons expressing $\alpha$-synuclein during the embryonic period become "tolerant" to accumulation of this protein at the later stages of development. In contrast, oligodendrocytes that normally express very little, if any, $\alpha$-synuclein are much more sensitive to forced accumulation of this protein, which resembles the situation with ectopic expression of $\alpha$-synuclein in invertebrates neurons (see below). Nevertheless it should be noted, that low levels of exogenous $\alpha$-synuclein expression are still not sufficient for triggering pathology in oligodendrocytes, i.e., a threshold level of expression and accumulation should be reached. In this aspect, it would be interesting to reveal if mutant forms of $\alpha$-synuclein that induced pathology in neurons much more effectively than wild type $\alpha$-synuclein would be also more effective in triggering pathology in oligodendrocytes where transport of this protein from cell body to presynaptic terminals is not an issue.

\section{Invertebrate Models of Synucleinopaties and the Role of Endogenous $\alpha$-Synuclein}

Substantial pathological changes were observed in several studies of mice expressing human 
$\alpha$-synuclein but lacking endogenous mouse $\alpha$-synuclein (Cabin et al., 2005; Chandra et al., 2005; Tofaris et al., 2006; Gallardo et al., 2008). Although only one study directly demonstrated that the severity of pathology increases at $\alpha$-synuclein null background (Cabin et al., 2005), it has been suggested that the endogenous protein has neuroprotective function(s). A possible scenario is that expression of endogenous $\alpha$-synuclein in developing embryonic neurons makes them tolerant to this protein, e.g., certain intracellular pathways become permanently active (or permanently inactive), which helps these cells to combat, to some extent, increased expression of this protein at later stages of life. In contrast, neurons that never express $\alpha$-synuclein during development and therefore never get prompted to develop such defense mechanisms become vulnerable to this protein. Importantly, the vulnerability to $\alpha$-synuclein toxicity does not equate with increased sensitivity to other toxic insults; conversely, increased resistance to $\alpha$-synuclein toxicity does not necessarily make cells generally more robust. Moreover, a particular combination of active/inactive signalling pathways might increase sensitivity to one and resistance to another type of toxic factor (see below). However, other mechanisms of neuroprotection by endogenous $\alpha$-synuclein could also be suggested and our current knowledge is far from sufficient in choosing between many possible explanations.

However, the absence of endogenous $\alpha$-synuclein could explain why invertebrates that lack any synuclein-like proteins readily develop pathological features typical for human synucleinopathies upon ectopic expression of $\alpha$-synuclein in their neurons. Expression of wild type, A53T or A30P human $\alpha$-synuclein in transgenic Drosophila melanogaster flies resulted in aggregation of $\alpha$-synuclein, formation of intracellular inclusions, progressive loss of dopaminergic neurons and changes of locomotor behaviour (Feany and Bender, 2000). Similarly, loss of dopaminergic neurons and their axons, reduction of dopamine level and motor dysfunction were characteristic for transgenic Caenorhabditis elegans worms, expressing wild type or mutant human $\alpha$-synuclein (Lakso et al., 2003; Kuwahara et al., 2006).

Neither neuronal loss nor $\alpha$-synuclein oligomers, fibrils or inclusions were found in the nervous sys- tem of transgenic flies expressing a deletion mutant of human $\alpha$-synuclein (lacking an internal fragment between amino acids 71 and 82) that shows decreased propensity to aggregate in vitro. In contrast, expression of a C-terminally truncated protein led to its aggregation into large intraneuronal inclusions and neuronal death (Periquet et al., 2007). These results suggested that aggregation and inclusion formation are required for neurotoxic effects of ectopically expressed $\alpha$-synuclein. However, studies of another line of transgenic flies demonstrated that co-expression of a chaperon, Hsp70, could rescue dopaminergic neurons from $\alpha$-synuclein-induced death but has no effect on $\alpha$-synuclein aggregation or inclusion formation in surviving neurons (Auluck et al., 2002). Therefore, studies of transgenic flies, as described in the above studies of transgenic mice, failed to resolve ambiguities about the role of aggregation in $\alpha$-synuclein-induced neurotoxicity.

\section{Protective Function of Endogenous $\alpha$-Synuclein and its Role in the Development of Neurodegeneration}

In the healthy nervous system $\alpha$-synuclein is localised nearly exclusively in presynaptic terminal, suggesting that it has important functions in this neuronal compartment (Maroteaux et al., 1988; Maroteaux and Scheller, 1991; Jakes et al., 1994). It has been suggested that $\alpha$-synuclein plays an important role in synaptoprotection (Chandra et $a l ., 2005)$ and, therefore, $\alpha$-synuclein dysfunction could lead to degeneration of synapses followed by retrograde death of neurons. Increased expression of $\alpha$-synuclein or expression of mutant forms trigger aggregation and compromise axonal trafficking of this protein (Saha et al., 2004). Consequently, $\alpha$-synuclein stacks in the neuronal cell body, and its synaptic pool gets gradually depleted, which makes synapses progressively vulnerable to various stress and other environmental factors. According to this hypothesis the loss of protective function of endogenous $\alpha$-synuclein is a substantial if not crucial event in the development of neurodegeneration in synucleinopathies. Another obvious conclusion is that animals lacking $\alpha$-synuclein should develop synaptic pathology followed by axonal and, finally, neuronal degeneration. However, this might be a simplistic conclusion, 
particularly if one takes into consideration that synapses and neurons of invertebrates survive perfectly well and function without $\alpha$-synuclein or any other synuclein-like proteins. Indeed, mice with targeted inactivation of $\alpha$-synuclein gene independently produced in several laboratories did not display any signs of neurodegeneration, although slight abnormalities of synaptic and mitochondrial functions and reduced numbers of neurons in certain populations have been reported (Abeliovich et al., 2000; Cabin et al., 2002; Dauer et al., 2002; Chandra et al., 2004; Robertson et al., 2004; Ellis et al., 2005). Moreover, animals supplied by Harlan UK to many laboratories as C57B16 wild type mice were found to carry a homozygous deletion of a locus that includes the whole $\alpha$-synuclein gene (Specht and Schoepfer, 2001).

A possible explanation for the absence of noticeable alterations in the nervous system of $\alpha$-synuclein null mutant mice is a functional compensation by two other closely related members of the synuclein family, $\beta$-synuclein and $\gamma$-synuclein. However, this idea got a substantial blow when no obvious phenotypical changes were observed in double $(\alpha / \gamma$ (Robertson et al., 2004) or $\alpha / \beta$ (Chandra et al., 2004)) or even in triple (our unpublished observations) synuclein null mutant mice. How is it possible that mouse neurons are so indifferent to the presence of such an evolutionary conserved and highly expressed protein? It could be suggested that developing embryonic neurons of null mutant mice switch on certain intrinsic mechanisms that compensate for the absence of synucleins. Activation of these mechanisms allows neurons to survive during critical developmental periods and function in adult nervous system. Although there is no experimental data that could give a clue about the nature of these intracellular mechanisms and their relationship with mechanisms that confer neurons tolerant to $\alpha$-synuclein (see above), one may speculate that activation of compensatory prosurvival processes/ pathways could make neurons less sensitive to certain toxic insults. Indeed, dopaminergic neurons of substantia nigra pars compacta of $\alpha$-synuclein and $\gamma$-synuclein null mutant mice were found to be resistant to toxic effects of MPTP, paraquat, 3-NP and malonate (Dauer et al., 2002; Drolet et al., 2004; Robertson et al., 2004; Fornai et al., 2005; Klivenyi et al., 2006; and our unpublished data). However, the same neurons might be more sensitive to other factors or changes of intracellular metabolism, for instance to overexpression of $\alpha$-synuclein later in the development (see above). Another example is accelerated development in mice lacking two members of the synuclein family, $\alpha$-synuclein and $\beta$-synuclein, of neurodegeneration triggered by the absence of synaptic co-chaperone $\operatorname{CSP} \alpha$ (Chandra et al., 2005). Moreover, increased expression of functional $\alpha$-synuclein in $\operatorname{CSP} \alpha$ null mutant mice rescued degeneration of synapses. These results directly demonstrated that $\alpha$-synuclein could protect synapses and neurons from particular pathological processes.

Interestingly, substantial impairment of synaptic function was observed in the nigrostriatal system of ageing $\alpha$-synuclein null mutant animals (our unpublished data). This suggests that although dopaminergic neurons are able to compensate for the absence of $\alpha$-synuclein, this requires mobilisation of other protective systems, whose efficiency declines in an ageing organism. As the result, neuronal compartments that are normally rich in $\alpha$-synuclein, first of all presynaptic terminals, become unprotected, which leads to their dysfunction and degeneration.

A growing body of evidence suggests that depletion of the synaptic pool of $\alpha$-synuclein contributes to the development of neurodegeneration in patients and in animal models of synucleinopathies but it is not clear how substantial this contribution could be. Currently available tools are not adequate for approaching the problem - new animal models are desperately needed that will allow tightly regulated conditional inactivation of $\alpha$-synuclein expression in vivo. This will eliminate the impact of developmental compensation and should clarify the role of endogenous $\alpha$-synuclein in the adult, ageing and degenerating nervous system.

\section{CONCLUSIONS}

Studies of animals with modified expression of $\alpha$-synuclein produced a wealth of data that substantially improved our understanding of aetiology and pathogenesis of synucleinopaties. However, many important questions still remain unanswered due to the complexity of the process and relative 
simplicity of animal models created so far. New more sophisticated models with tightly regulated and conditional expression of $\alpha$-synuclein as well as other members of the family are urgently required. To get better juice one should squeeze better fruits.

\section{Acknowledgements}

We are gratefull to Steven Millership and Owen Peters for critical reading of the manuscript. This work was supported by a grant from The Wellcome Trust.

\section{References}

Abeliovich A, Schmitz Y, Farinas I, Choi-Lundberg D, Ho WH, Castillo PE, Shinsky N, Verdugo JM, Armanini M, Ryan A, Hynes M, Phillips H, Sulzer D, Rosenthal A (2000) Mice lacking $\alpha$-synuclein display functional deficits in the nigrostriatal dopamine system. Neuron 25, 239-252.

Auluck PK, Chan HY, Trojanowski JQ, Lee VM, Bonini NM (2002) Chaperone suppression of $\alpha$-synuclein toxicity in a Drosophila model for Parkinson's disease. Science 295, 865868.

Bar-On P, Rockenstein E, Adame A, Ho G, Hashimoto M, Masliah E (2006) Effects of the cholesterol-lowering compound methyl- $\beta$-cyclodextrin in models of $\alpha$-synucleinopathy. J. Neurochem. 98, 1032-1045.

Cabin DE, Shimazu K, Murphy D, Cole NB, Gottschalk W, McIlwain KL, Orrison B, Chen A, Ellis CE, Paylor R, Lu B, Nussbaum RL (2002) Synaptic vesicle depletion correlates with attenuated synaptic responses to prolonged repetitive stimulation in mice lacking $\alpha$-synuclein. $J$. Neurosci. 22, 8797-8807.

Cabin DE, Gispert-Sanchez S, Murphy D, Auburger G, Myers RR, Nussbaum RL (2005) Exacerbated synucleinopathy in mice expressing A53T SNCA on a Snca null background. Neurobiol. Aging 26, 25-35.

Caughey B, Lansbury PT (2003) Protofibrils, pores, fibrils, and neurodegeneration: separating the responsible protein aggregates from the innocent bystanders. Annu. Rev. Neurosci. 26, 267-298.

Chandra S, Fornai F, Kwon HB, Yazdani U, Atasoy D, Liu X, Hammer RE, Battaglia G, German DC, Castillo PE, Sudhof TC (2004) Double-knockout mice for $\alpha$ - and $\beta$-synucleins: effect on synaptic functions. Proc. Natl. Acad. Sci. USA 101, 14966-14971.

Chandra S, Gallardo G, Fernandez-Chacon R, Schluter OM, Sudhof TC (2005) $\alpha$-Synuclein cooperates with $\operatorname{CSP} \alpha$ in preventing neurodegeneration. Cell 123, 383-396.

Chen L, Thiruchelvam MJ, Madura K, Richfield EK (2006) Proteasome dysfunction in aged human $\alpha$-synuclein transgenic mice. Neurobiol. Dis. 23, 120-126.

Dauer W, Kholodilov N, Vila M, Trillat AC, Goodchild R, Larsen KE, Staal R, Tieu K, Schmitz Y, Yuan CA, Rocha M,
Jackson-Lewis V, Hersch S, Sulzer D, Przedborski S, Burke R, Hen R (2002) Resistance of $\alpha$-synuclein null mice to the parkinsonian neurotoxin MPTP. Proc. Natl. Acad. Sci. USA 99, 14524-14529.

Dev KK, Hofele K, Barbieri S, Buchman VL, van der Putten H (2003) Part II: $\alpha$-Synuclein and its molecular pathophysiologicalroleinneurodegenerativedisease. Neuropharmacology 45, 14-44.

Drolet RE, Behrouz B, Lookingland KJ, Goudreau JL (2004) Mice lacking $\alpha$-synuclein have an attenuated loss of striatal dopamine following prolonged chronic MPTP administration. Neurotoxicology 25, 761-769.

Ellis CE, Murphy EJ, Mitchell DC, Golovko MY, Scaglia F, Barcelo-Coblijn GC, Nussbaum RL (2005) Mitochondrial lipid abnormality and electron transport chain impairment in mice lacking $\alpha$-synuclein. Mol. Cell. Biol. 25, 1019010201.

Farrer M, Kachergus J, Forno L, Lincoln S, Wang DS, Hulihan M, Maraganore D, Gwinn-Hardy K, Wszolek Z, Dickson D, Langston JW (2004) Comparison of kindreds with parkinsonism and $\alpha$-synuclein genomic multiplications. Ann. Neurol. 55, 174-179.

Feany MB, Bender WW (2000) A Drosophila model of Parkinson's disease. Nature 404, 394-398.

Fernagut PO, Hutson CB, Fleming SM, Tetreaut NA, Salcedo J, Masliah E, Chesselet MF (2007) Behavioral and histopathological consequences of paraquat intoxication in mice: effects of $\alpha$-synuclein over-expression. Synapse 61, 9911001.

Fink AL (2006) The aggregation and fibrillation of $\alpha$-synuclein. Acc. Chem. Res. 39, 628-634.

Fleming SM, Salcedo J, Fernagut PO, Rockenstein E, Masliah E, Levine MS, Chesselet MF (2004) Early and progressive sensorimotor anomalies in mice overexpressing wild-type human $\alpha$-synuclein. $J$. Neurosci. 24, 9434-9440.

Fleming SM, Salcedo J, Hutson CB, Rockenstein E, Masliah E, Levine MS, Chesselet MF (2006) Behavioral effects of dopaminergic agonists in transgenic mice overexpressing human wildtype $\alpha$-synuclein. Neuroscience 142, 1245-1253.

Fornai F, Schluter OM, Lenzi P, Gesi M, Ruffoli R, Ferrucci M, Lazzeri G, Busceti CL, Pontarelli F, Battaglia G, Pellegrini A, Nicoletti F, Ruggieri S, Paparelli A, Sudhof TC (2005) Parkinson-like syndrome induced by continuous MPTP infusion: convergent roles of the ubiquitin-proteasome system and $\alpha$-synuclein. Proc. Natl. Acad. Sci. USA 102, 34133418.

Fortin DL, Troyer MD, Nakamura K, Kubo S, Anthony MD, Edwards RH (2004) Lipid rafts mediate the synaptic localization of $\alpha$-synuclein. J. Neurosci. 24, 6715-6723.

Frasier M, Walzer M, McCarthy L, Magnuson D, Lee JM, Haas C, Kahle P, Wolozin B (2005) Tau phosphorylation increases in symptomatic mice overexpressing A30P $\alpha$-synuclein. Exp. Neurol. 192, 274-287.

Freichel C, Neumann M, Ballard T, Muller V, Woolley M, Ozmen L, Borroni E, Kretzschmar HA, Haass C, Spooren W, Kahle PJ (2007) Age-dependent cognitive decline and amygdala pathology in $\alpha$-synuclein transgenic mice. Neurobiol. Aging 28, 1421-1435.

Gallardo G, Schluter OM, Sudhof TC (2008) A molecular path- 
way of neurodegeneration linking $\alpha$-synuclein to ApoE and A $\beta$ peptides. Nat. Neurosci. 11, 301-308.

Galvin JE, Lee VM, Trojanowski JQ (2001) Synucleinopathies: clinical and pathological implications. Arch. Neurol. 58, 186-190.

Giasson BI, Duda JE, Quinn SM, Zhang B, Trojanowski JQ, Lee VM (2002) Neuronal $\alpha$-synucleinopathy with severe movement disorder in mice expressing A53T human $\alpha$-synuclein. Neuron 34, 521-533.

Gispert S, Del Turco D, Garrett L, Chen A, Bernard DJ, Hamm-Clement J, Korf HW, Deller T, Braak H, Auburger G, Nussbaum RL (2003) Transgenic mice expressing mutant A53T human $\alpha$-synuclein show neuronal dysfunction in the absence of aggregate formation. Mol. Cell. Neurosci. 24, 419-429.

Goedert M, Spillantini MG (1998) Lewy body diseases and multiple system atrophy as $\alpha$-synucleinopathies. Mol. Psychiatry 3, 462-465.

Gomez-Isla T, Irizarry MC, Mariash A, Cheung B, Soto O, Schrump S, Sondel J, Kotilinek L, Day J, Schwarzschild MA, Cha JH, Newell K, Miller DW, Ueda K, Young AB, Hyman BT, Ashe KH (2003) Motor dysfunction and gliosis with preserved dopaminergic markers in human $\alpha$-synuclein A30P transgenic mice. Neurobiol. Aging 24, 245-258.

Hashimoto M, Rockenstein E, Mante M, Mallory M, Masliah E (2001) $\beta$-Synuclein inhibits $\alpha$-synuclein aggregation: a possible role as an anti-parkinsonian factor. Neuron 32, 213223.

Hashimoto M, Rockenstein E, Mante M, Crews L, Bar-On P, Gage FH, Marr R, Masliah E (2004) An antiaggregation gene therapy strategy for Lewy body disease utilizing $\beta$-synuclein lentivirus in a transgenic model. Gene Ther. 11, 1713-1723.

Jakes R, Spillantini MG, Goedert M (1994) Identification of two distinct synucleins from human brain. FEBS Lett. 345, 27-32.

Kahle PJ, Neumann M, Ozmen L, Muller V, Jacobsen H, Schindzielorz A, Okochi M, Leimer U, van Der Putten H, Probst A, Kremmer E, Kretzschmar HA, Haass C (2000) Subcellular localization of wild-type and Parkinson's disease-associated mutant $\alpha$-synuclein in human and transgenic mouse brain. J. Neurosci. 20, 6365-6373.

Kahle PJ, Neumann M, Ozmen L, Muller V, Odoy S, Okamoto N, Jacobsen H, Iwatsubo T, Trojanowski JQ, Takahashi H, Wakabayashi K, Bogdanovic N, Riederer P, Kretzschmar HA, Haass C (2001) Selective insolubility of $\alpha$-synuclein in human Lewy body diseases is recapitulated in a transgenic mouse model. Am. J. Pathol. 159, 2215-2225.

Kahle PJ, Neumann M, Ozmen L, Muller V, Jacobsen H, Spooren W, Fuss B, Mallon B, Macklin WB, Fujiwara H, Hasegawa M, Iwatsubo T, Kretzschmar HA, Haass C (2002) Hyperphosphorylation and insolubility of $\alpha$-synuclein in transgenic mouse oligodendrocytes. EMBO Rep. 3, 583588.

Klivenyi P, Siwek D, Gardian G, Yang L, Starkov A, Cleren C, Ferrante RJ, Kowall NW, Abeliovich A, Beal MF (2006) Mice lacking $\alpha$-synuclein are resistant to mitochondrial toxins. Neurobiol. Dis. 21, 541-548.

Klucken J, Shin Y, Masliah E, Hyman BT, McLean PJ (2004)
Hsp70 Reduces $\alpha$-synuclein aggregation and toxicity. $J$. Biol. Chem. 279, 25497-25502.

Kuwahara T, Koyama A, Gengyo-Ando K, Masuda M, Kowa H, Tsunoda M, Mitani S, Iwatsubo T (2006) Familial Parkinson mutant $\alpha$-synuclein causes dopamine neuron dysfunction in transgenic Caenorhabditis elegans. J. Biol. Chem. 281, 334-340.

Lakso M, Vartiainen S, Moilanen AM, Sirvio J, Thomas JH, Nass R, Blakely RD, Wong G (2003) Dopaminergic neuronal loss and motor deficits in Caenorhabditis elegans overexpressing human $\alpha$-synuclein. J. Neurochem. 86, 165172.

Lee MK, Stirling W, Xu Y, Xu X, Qui D, Mandir AS, Dawson TM, Copeland NG, Jenkins NA, Price DL (2002) Human $\alpha$-synuclein-harboring familial Parkinson's disease-linked Ala-53 --> Thr mutation causes neurodegenerative disease with $\alpha$-synuclein aggregation in transgenic mice. Proc. Natl. Acad. Sci. USA 99, 8968-8973.

Manning-Bog AB, McCormack AL, Purisai MG, Bolin LM, Di Monte DA (2003) $\alpha$-Synuclein overexpression protects against paraquat-induced neurodegeneration. J. Neurosci. 23, 3095-3099.

Maroteaux L, Scheller RH (1991) The rat brain synucleins; family of proteins transiently associated with neuronal membrane. Brain Res. Mol. Brain Res. 11, 335-343.

Maroteaux L, Campanelli JT, Scheller RH (1988) Synuclein: a neuron-specific protein localized to the nucleus and presynaptic nerve terminal. J. Neurosci. 8, 2804-2815.

Marti MJ, Tolosa E, Campdelacreu J (2003) Clinical overview of the synucleinopathies. Mov. Disord. 18 Suppl. 6, S21S27.

Martin LJ, Pan Y, Price AC, Sterling W, Copeland NG, Jenkins NA, Price DL, Lee MK (2006) Parkinson's disease $\alpha$-synuclein transgenic mice develop neuronal mitochondrial degeneration and cell death. J. Neurosci. 26, 41-50.

Maskri L, Zhu X, Fritzen S, Kuhn K, Ullmer C, Engels P, Andriske M, Stichel CC, Lubbert H (2004) Influence of different promoters on the expression pattern of mutated human $\alpha$-synuclein in transgenic mice. Neurodegen. Dis. 1, 255265.

Masliah E, Rockenstein E, Veinbergs I, Mallory M, Hashimoto M, Takeda A, Sagara Y, SiskA, Mucke L (2000) Dopaminergic loss and inclusion body formation in $\alpha$-synuclein mice: implications for neurodegenerative disorders. Science 287, 1265-1269.

Masliah E, Rockenstein E, Veinbergs I, Sagara Y, Mallory M, Hashimoto M, Mucke L (2001) $\beta$-Amyloid peptides enhance $\alpha$-synuclein accumulation and neuronal deficits in a transgenic mouse model linking Alzheimer's disease and Parkinson's disease. Proc. Natl. Acad. Sci. USA 98, 1224512250.

Masliah E, Rockenstein E, Adame A, Alford M, Crews L, Hashimoto M, Seubert P, Lee M, Goldstein J, Chilcote T, Games D, Schenk D (2005) Effects of $\alpha$-synuclein immunization in a mouse model of Parkinson's disease. Neuron 46, 857-868.

Matsuoka Y, Vila M, Lincoln S, McCormack A, Picciano M, LaFrancois J, Yu X, Dickson D, Langston WJ, McGowan E, Farrer M, Hardy J, Duff K, Przedborski S, Di Monte DA 
(2001) Lack of nigral pathology in transgenic mice expressing human $\alpha$-synuclein driven by the tyrosine hydroxylase promoter. Neurobiol. Dis. 8, 535-539.

Michell AW, Tofaris GK, Gossage H, Tyers P, Spillantini MG, Barker RA (2007) The effect of truncated human $\alpha$-synuclein (1-120) on dopaminergic cells in a transgenic mouse model of Parkinson's disease. Cell Transplant. 16, 461-474.

Neumann M, Kahle PJ, Giasson BI, Ozmen L, Borroni E, Spooren W, Muller V, Odoy S, Fujiwara H, Hasegawa M, Iwatsubo T, Trojanowski JQ, Kretzschmar HA, Haass C (2002) Misfolded proteinase K-resistant hyperphosphorylated $\alpha$-synuclein in aged transgenic mice with locomotor deterioration and in human $\alpha$-synucleinopathies. J. Clin. Invest. 110, 1429-1439.

Nieto M, Gil-Bea FJ, Dalfo E, Cuadrado M, Cabodevilla F, Sanchez B, Catena S, Sesma T, Ribe E, Ferrer I, Ramirez MJ, Gomez-Isla T (2006) Increased sensitivity to MPTP in human $\alpha$-synuclein A30P transgenic mice. Neurobiol. Aging 27, 848-856.

Periquet M, Fulga T, Myllykangas L, Schlossmacher MG, Feany MB (2007) Aggregated $\alpha$-synuclein mediates dopaminergic neurotoxicity in vivo. J. Neurosci. 27, 33383346.

Polymeropoulos MH, Lavedan C, Leroy E, Ide SE, Dehejia A, Dutra A, Pike B, Root H, Rubenstein J, Boyer R, Stenroos ES, Chandrasekharappa S, Athanassiadou A, Papapetropoulos T, Johnson WG, Lazzarini AM, Duvoisin RC, Di Iorio G, Golbe LI, Nussbaum RL (1997) Mutation in the $\alpha$-synuclein gene identified in families with Parkinson's disease. Science 276, 2045-2047.

Poon HF, Frasier M, Shreve N, Calabrese V, Wolozin B, Butterfield DA (2005) Mitochondrial associated metabolic proteins are selectively oxidized in $\mathrm{A} 30 \mathrm{P} \alpha$-synuclein transgenic mice - a model of familial Parkinson's disease. Neurobiol. Dis. 18, 492-498.

Rathke-Hartlieb S, Kahle PJ, Neumann M, Ozmen L, Haid S, Okochi M, Haass C, Schulz JB (2001) Sensitivity to MPTP is not increased in Parkinson's disease-associated mutant $\alpha$-synuclein transgenic mice. $J$. Neurochem. 77, 1181-1184.

Richfield EK, Thiruchelvam MJ, Cory-Slechta DA, Wuertzer C, Gainetdinov RR, Caron MG, Di Monte DA, Federoff HJ (2002) Behavioral and neurochemical effects of wild-type and mutated human $\alpha$-synuclein in transgenic mice. Exp. Neurol. 175, 35-48.

Robertson DC, Schmidt O, Ninkina N, Jones PA, Sharkey J, Buchman VL (2004) Developmental loss and resistance to MPTP toxicity of dopaminergic neurones in substantia nigra pars compacta of $\gamma$-synuclein, $\alpha$-synuclein and double $\alpha / \gamma$ synuclein null mutant mice. J. Neurochem. 89, 1126-1136.

Rockenstein E, Mallory M, Hashimoto M, Song D, Shults CW, Lang I, Masliah E (2002) Differential neuropathological alterations in transgenic mice expressing $\alpha$-synuclein from the platelet-derived growth factor and Thy-1 promoters. $J$. Neurosci. Res. 68, 568-578.

Saha AR, Hill J, Utton MA, Asuni AA, Ackerley S, Grierson AJ, Miller CC, Davies AM, Buchman VL, Anderton BH, Hanger DP (2004) Parkinson's disease $\alpha$-synuclein mutations exhibit defective axonal transport in cultured neurons. J. Cell. Sci. 117, 1017-1024.
Sharon R, Goldberg MS, Bar-Josef I, Betensky RA, Shen J, Selkoe DJ (2001) $\alpha$-Synuclein occurs in lipid-rich high molecular weight complexes, binds fatty acids, and shows homology to the fatty acid-binding proteins. Proc. Natl. Acad. Sci. USA 98, 9110-9115.

Sharon R, Bar-Joseph I, Frosch MP, Walsh DM, Hamilton JA, Selkoe DJ (2003) The formation of highly soluble oligomers of $\alpha$-synuclein is regulated by fatty acids and enhanced in Parkinson's disease. Neuron 37, 583-595.

Shults CW, Rockenstein E, Crews L, Adame A, Mante M, Larrea G, Hashimoto M, Song D, Iwatsubo T, Tsuboi K, Masliah E (2005) Neurological and neurodegenerative alterations in a transgenic mouse model expressing human $\alpha$-synuclein under oligodendrocyte promoter: implications for multiple system atrophy. J. Neurosci. 25, 10689-10699.

Singleton AB, Farrer M, Johnson J, Singleton A, Hague S, Kachergus J, Hulihan M, Peuralinna T, Dutra A, Nussbaum R, Lincoln S, Crawley A, Hanson M, Maraganore D, Adler C, Cookson MR, Muenter M, Baptista M, Miller D, Blancato J, Hardy J, Gwinn-Hardy K (2003) $\alpha$-Synuclein locus triplication causes Parkinson's disease. Science 302, 841.

Song DD, Shults CW, Sisk A, Rockenstein E, Masliah E (2004) Enhanced substantia nigra mitochondrial pathology in human $\alpha$-synuclein transgenic mice after treatment with MPTP. Exp. Neurol. 186, 158-172.

Specht CG, Schoepfer R (2001) Deletion of the $\alpha$-synuclein locus in a subpopulation of $\mathrm{C} 57 \mathrm{BL} / 6 \mathrm{~J}$ inbred mice. $B M C$ Neurosci. 2, 11.

Spillantini MG, Goedert M (2000) The $\alpha$-synucleinopathies: Parkinson's disease, dementia with Lewy bodies, and multiple system atrophy. Ann. NY Acad. Sci. 920, 16-27.

Spillantini MG, Schmidt ML, Lee VM, Trojanowski JQ, Jakes $\mathrm{R}$, Goedert M (1997) $\alpha$-Synuclein in Lewy bodies. Nature 388, 839-840.

Stefanova N, Reindl M, Neumann M, Haass C, Poewe W, Kahle PJ, Wenning GK (2005) Oxidative stress in transgenic mice with oligodendroglial $\alpha$-synuclein overexpression replicates the characteristic neuropathology of multiple system atrophy. Am. J. Pathol. 166, 869-876.

Stefanova N, Poewe W, Wenning GK (2007a) Rasagiline is neuroprotective in a transgenic model of multiple system atrophy. Exp. Neurol. 210, 421-427.

Stefanova N, Reindl M, Neumann M, Kahle PJ, Poewe W, Wenning GK (2007b) Microglial activation mediates neurodegeneration related to oligodendroglial $\alpha$-synucleinopathy: implications for multiple system atrophy. Mov. Disord. 22, 2196-2203.

Stefanova N, Kollensperger M, Hainzer M, Cenci A, Poewe W, Wenning GK (2007c) High dose levodopa therapy is not toxic in multiple system atrophy: experimental evidence. Mov. Disord. 22, 969-973.

Stichel CC, Zhu XR, Bader V, Linnartz B, Schmidt S, Lubbert $\mathrm{H}$ (2007) Mono- and double-mutant mouse models of Parkinson's disease display severe mitochondrial damage. Hum. Mol. Genet. 16, 3377-3393.

Thiruchelvam MJ, Powers JM, Cory-Slechta DA, Richfield EK (2004) Risk factors for dopaminergic neuron loss in human $\alpha$-synuclein transgenic mice. Eur. J. Neurosci. 19, 845-854.

Tofaris GK, Garcia Reitbock P, Humby T, Lambourne SL, 
O'Connell M, Ghetti B, Gossage H, Emson PC, Wilkinson LS, Goedert M, Spillantini MG (2006) Pathological changes in dopaminergic nerve cells of the substantia nigra and olfactory bulb in mice transgenic for truncated human $\alpha$-synuclein(1-120): implications for Lewy body disorders. J. Neurosci. 26, 3942-3950.

Unger EL, Eve DJ, Perez XA, Reichenbach DK, Xu Y, Lee MK, Andrews AM (2006) Locomotor hyperactivity and alterations in dopamine neurotransmission are associated with overexpression of A53T mutant human $\alpha$-synuclein in mice. Neurobiol. Dis. 21, 431-443.

Uversky VN (2007) Neuropathology, biochemistry, and biophysics of $\alpha$-synuclein aggregation. J. Neurochem. 103, $17-37$.

Uversky VN, Fink AL (2002) Amino acid determinants of $\alpha$-synuclein aggregation: putting together pieces of the puzzle. FEBS Lett. 522, 9-13.

van der Putten H, Wiederhold KH, Probst A, Barbieri S, Mistl C, Danner S, Kauffmann S, Hofele K, Spooren WP, Ruegg MA, Lin S, Caroni P, Sommer B, Tolnay M, Bilbe G (2000) Neuropathology in mice expressing human $\alpha$-synuclein. $J$. Neurosci. 20, 6021-6029.

Wakamatsu M, Ishii A, Ukai Y, Sakagami J, Iwata S, Ono M, Matsumoto K, Nakamura A, Tada N, Kobayashi K, Iwatsubo T, Yoshimoto M (2007) Accumulation of phosphorylated $\alpha$-synuclein in dopaminergic neurons of transgenic mice that express human $\alpha$-synuclein. J. Neurosci. Res. 85, 18191825.

Wakamatsu M, Ishii A, Iwata S, Sakagami J, Ukai Y, Ono M, Kanbe D, Muramatsu S, Kobayashi K, Iwatsubo T, Yoshimoto M (2008) Selective loss of nigral dopamine neurons induced by overexpression of truncated human $\alpha$-synuclein in mice. Neurobiol. Aging 29, 574-585.

Winner B, Lie DC, Rockenstein E, Aigner R, Aigner L, Masliah E, Kuhn HG, Winkler J (2004) Human wild-type $\alpha$-synuclein impairs neurogenesis. J. Neuropathol. Exp. Neurol. 63, 1155-1166.

Winner B, Rockenstein E, Lie DC, Aigner R, Mante M, Bogdahn U, Couillard-Despres S, Masliah E, Winkler J (2008) Mutant $\alpha$-synuclein exacerbates age-related decrease of neurogenesis. Neurobiol. Aging 29, 913-925.

Yazawa I, Giasson BI, Sasaki R, Zhang B, Joyce S, Uryu K, Trojanowski JQ, Lee VM (2005) Mouse model of multiple system atrophy $\alpha$-synuclein expression in oligodendrocytes causes glial and neuronal degeneration. Neuron 45, 847859.

Zhou W, Schutzman J, Freed CR (2008) Transgenic mice overexpressing tyrosine-to-cysteine mutant human $\alpha$-synuclein: a progressive neurodegenerative model of diffuse Lewy body disease. J. Biol. Chem. 283, 9863-9870. 